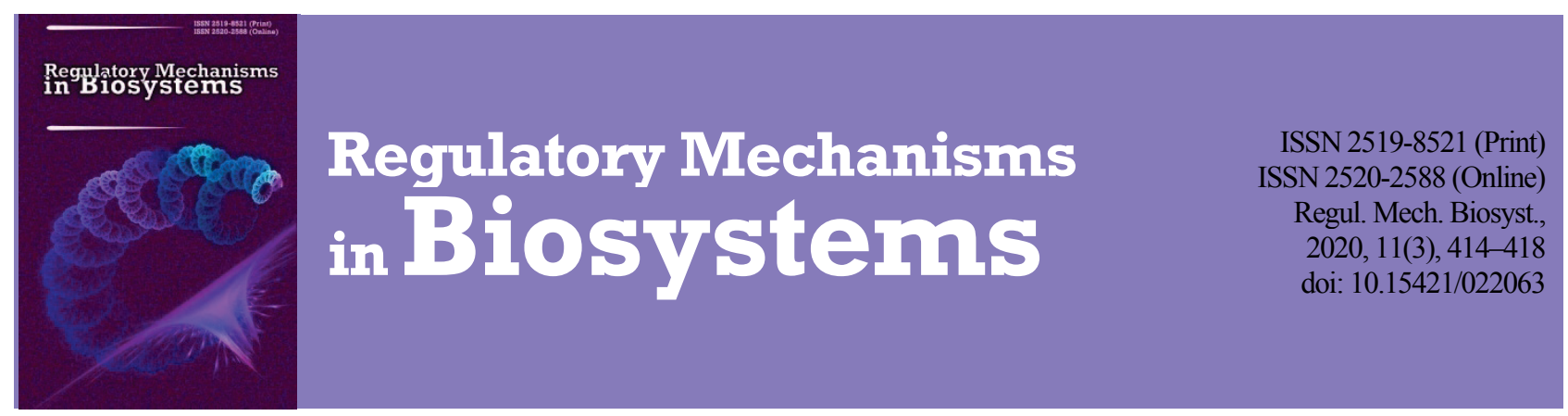

\title{
The influence of hydro-meteorological conditions on the spread of chicken cestodiasis
}

\author{
M. V. Bogach*, A. P. Paliy**, L. V. Perots'ka***, I. V. Pyvovarova***, V. Y. Stoyanova*, A. P. Palii**** \\ *Odessa Experimental Station National Scientific Center "Institute of Experimental and Clinical Veterinary Medicine", Odessa, Ukraine \\ **National Scientific Center "Institute of Experimental and Clinical Veterinary Medicine", Kharkiv, Ukraine \\ ***Odessa State Agrarian University, Odessa, Ukraine \\ ****Kharkiv Petro Vasylenko National Technical University of Agriculture, Kharkiv, Ukraine
}

Article info

Received 02.07.2020

Received in revised form 16.07.2020

Accepted 18.07.2020

Odessa Experimental Station National Scientific Center "Institute of Experimental and Clinical Veterinary Medicine", Svobody Ave., 2, Odessa, 65037, Ukraine. Tel.: +38-067-997-49-25. E-mail:bogachnv@ukr.net

National Scientific Center "Institute of Experimental and Clinical Veterinary Medicine”, Pushkinska st., 83, Kharkiv, 61023, Ukraine. Tel.: +38-066-225-3434.E-mail:paliy.dok@gmail.com

Odesa State Agrarian University, Panteleymonovska st., 13, Odessa, 65000, Ukraine. Tel.: + 380-067-785-61 94.E-mail:perotskaya@ukr.net

Kharkiv Petro Vasylenko National Technical University of Agriculture, Alchevskyh st., 44, Kharkiv, 61002 Ukraine. Tel.: +38-063-712-82-42. E-mail:paliy.andriy@ukr.net

\section{Introduction}

In recent years the poultry industry in Ukraine has experienced stable and confident development and hens, ducks, geese, turkeys, quails, guinea fowl and ostriches are kept on small farms as well as large. However, modern progressive poultry rearing technology has led to a number of new production problems associated with the decrease in its viability and productivity and has a number of environmental hazards (Sonntag et al., 2019). Thus a whole series of pollutants, pathogenic and conditionally pathogenic microorganisms, helminth eggs, natural and synthetic hormones, veterinary antimicrobial agents and heavy metals are excreted from the birds' manure and all of them can reach the surface of soils in local agricultural land, surface and ground waters and pose direct and indirect risks to human health (Hu et al., 2017). It was determined that the average level of soil pollution in rural areas with helminth eggs (strongilates, ascaridates, trichocephalates, cestodes and trematodes) is $12.5 \%$ (Boyko et al., 2009, 2016; Paliy et al., 2019).

Dense concentrations of birds in limited areas, violation of rules of feeding and poultry maintenance, changes in temperature, humidity and other environmental parameters lead to the decrease in the bird's protective barrier, the development of many infections and invasions due to the activation of opportunistic microflora and potential conditions for the development of bacterial, viral and endoparasitic diseases (Cadmus et al.,
2019). The development of the poultry industry and the production of safe and high quality products are possible only with a stable epizootic situation concerning diseases of infectious and invasive etiology (Lorencena et al., 2018).

It has been established that at industrial poultry enterprises in Ukraine, the most common ectoparasites are red chicken ticks (Dermanissus gallinae (De Geer, 1778)), also feather lice infest chickens and turkeys (Menopon gallinae (Linnaeus, 1758), Menacanthus stramineus (Nitzsch, 1818)) and the chicken tick is found on pigeons that live in homesteads. It has been proven that ectoparasites quickly spread when veterinary sanitary norms and rules are not followed and mechanical carriers are present (attendants, synanthropic birds, mice, etc.) and egg containers are used repeatedly without special treatment measures (Paliy et al., 2018).

The most common parasitic diseases in birds are helminthiases. Intestinal infestations cause great economic damage to the poultry industry: we can observe lagging in growth and development of the birds, and sometimes their death from general depletion and intoxication by parasite metabolism products, a significant decrease in egg production, an increase in feed costs per unit of growth, etc. Helminths also cause the appearance of hypovitaminosis, which inhibits immune states, and they also contribute to the penetration of pathogens of various infectious diseases (McSorley \& Maizels, 2012; Hübner et al., 2013). In the conditions of the Steppe and Forest-Steppe of Ukraine, bird cestodiasis is registered, which most often 
is caused by raillietinosis and daveniosis (Bogach et al., 2019; Bogach \& Stoyanova, 2020). Raillietinosis is a fairly common parasitic disease, but mainly in countries with a tropical and hotter climate (Sreedevi et al., 2016) on the Africa continent (Eshetu et al., 2001), India (Puttalakshmamma et al. 2008), Jordan (Abdelqader et al., 2008), Iran (Radfar et al., 2012), Morocco (Hassouni \& Belghyti, 2006). The ambient temperature and high precipitation in the Jammu region create favourable conditions for the more rapid development and spread of various stages of nematodes and cestodes (Katoch et al., 2012).

Most parasites in the process of individual development at a certain stage penetrate into the environment and lead an independent mode of life. At this time, they are represented as typical components of the biocenosis and are directly dependent on environmental conditions (Karshima et al., 2018; Paliy et al., 2018). The dynamics of the population of helminths depends on the characteristics of their life cycle and the way of circulation of biocenoses (Wells et al., 2018; Winter et al., 2018).

The biotic factors in spreading of disease include the pathogen, the area of its circulation in biocenoses, the peculiarities of biology and ways of influences on the farm. Among the abiotic causes, the most significant are meteorological factors: temperature, humidity, lighting, and precipitation, on which the maturation, viability, and distribution of eggs and larvae of helminths and intermediate parasite hosts depend (Fox et al., 2012; Blum \& Hotez, 2018).

Since the middle of the 1980s in Odessa Region of Ukraine, deviations of certain weather factors from long-term average indicators have become significant, in particular, the number of warm winters has increased, and the average annual air temperature has increased by more than $3.5^{\circ} \mathrm{C}$ and the reserve of productive moisture in the soil has decreased, which affects the increase of ant populations - intermediate hosts of Raillietina. Despite the fact that there have been reports from various parts of the world about the spread of parasites in poultry, it is still necessary to conduct parasitological studies in other parts of the country, taking into account changes in temperature and humidity.

According to Stepanenko (2007), after 2005 long dry and hot periods were recorded in the southern regions of Eastern Europe and the Mediterranean. The observed global warming significantly affects sectors that depend on climatic conditions, including agriculture (Mendelsohn, 2008; Gornall et al., 2010).

Data on the influence of hydrometeorological conditions on the spread of chicken raillietinosis has not been found in the literature and they are not accessible to us. In this regard, the aim of the work was to determine the indicators of the extensivity and intensity of chicken raillietinosis on farms in Odessa Region of Ukraine, taking into account the hydrometeorological conditions in 2017 and 2019.

\section{Materials and methods}

During 2017, 1965 chickens of different age groups which are kept on the floor were studied. In 2019, 2254 chickens were investigated with helminth coproovoscopic tests. During the parasitological examination of chickens, the indicators of the defeat of the causative agents of cestodiasis - the extensivity (EI) and the intensity (II) of the invasion were determined and the number of eggs cestodes in $1 \mathrm{~g}$ of faecal was counted. For post-mortem diagnosis of cestodiasis, a small section of the intestine was taken from dead or killed chickens. The species of the detected helminth eggs was determined on the basis of morphological (colour, shape, size, number of shells) (Kapustin, 1953) and biological (degree of development of the embryo) features (Daxno \& Daxno, 2010) and the existing description (Saif et al., 2008).

The invasion intensity was determined by the formula:

$$
\mathrm{EI}=\mathrm{x} / \mathrm{y} \times 100
$$

where $\mathrm{EI}$ - invasion extensivity, $\mathrm{x}$ - number of fecal samples in which the helminth eggs were found, $\mathrm{y}$ - total number of fecal samples, 100 - percentage conversion factor.

Data on the amount of precipitation and average air temperature are obtained from the Bolgrad meteorological station (Bolgrad, Odessa Region). The hydrothermal coefficient (HTC) of Selyaninov (1937) was used to assess the moisture conditions of a period with average daily temperatures above $10{ }^{\circ} \mathrm{C}$, that is the period of active vegetation. In certain months of the year there are no active air temperatures above $10^{\circ} \mathrm{C}$, therefore, the HTC was not calculated. The hydrothermal coefficient (HTC) of Selyaninov was calculated by dividing the amount of precipitation $(\Sigma \mathrm{R})$ in $\mathrm{mm}$ for a period with temperatures above $10{ }^{\circ} \mathrm{C}$ by the sum of active temperatures ( $\Sigma \mathrm{t}$ act $>10)$ for the same period, reduced by 10 times:

$$
\mathrm{HTC}=\frac{\Sigma \mathrm{R}}{0,1 \cdot \Sigma \mathrm{t}_{\mathrm{act}}>10} \quad \text { or } \quad \mathrm{HTC}=\frac{\Sigma \mathrm{R} \cdot 10}{\Sigma \mathrm{t}_{\mathrm{act}}>10}
$$

if $\mathrm{HTC}<0.4$ - very severe drought, HTC from 0.4 to 0.5 - severe drought, HTC from 0.6 to 0.7 - moderate drought, HTC from 0.8 to 0.9 mild drought, HTC from 1.0 to 1.5 - quite wet, HTC $>1.5$ - excessively wet.

\section{Results}

During five months of 2017: January, February, March, November and December, the HTC ratio was not calculated due to the fact that the average daily temperature was below $10{ }^{\circ} \mathrm{C}$ (Table 1). For 4 months, HTC from 0.4 to 0.8 were recorded, indicating severe and moderate droughts.

Table 1

Characteristics of hydrometeorological conditions

\begin{tabular}{|c|c|c|c|c|}
\hline Months & $\begin{array}{c}\text { Precipitation, } \\
\mathrm{mm}\end{array}$ & $\begin{array}{c}\text { Average } \\
\text { temperature, }{ }^{\circ} \mathrm{C}\end{array}$ & $\begin{array}{c}\text { Sum of active } \\
\text { temperatures }\left(\mathrm{t}_{\mathrm{act}}>10\right),{ }^{\circ} \mathrm{C}\end{array}$ & HTC \\
\hline January & 27.9 & 1.2 & 0 & - \\
\hline February & 56.1 & 4.3 & 0 & - \\
\hline March & 42.9 & 8.7 & 0 & - \\
\hline April & 55.3 & 12.5 & 375 & 1.5 \\
\hline May & 52.4 & 17.2 & 533 & 1.0 \\
\hline June & 51.2 & 21.6 & 648 & 0.8 \\
\hline July & 34.7 & 24.7 & 766 & 0.5 \\
\hline August & 29.2 & 25.6 & 794 & 0.4 \\
\hline September & 42.9 & 17.2 & 516 & 0.8 \\
\hline October & 47.7 & 11.4 & 353 & 1.4 \\
\hline November & 31.7 & 9.8 & 0 & - \\
\hline December & 50.3 & 1.2 & 0 & - \\
\hline
\end{tabular}
in the south of Odessa Region for 2017

For three months, the moisture supply coefficient ranged from 1.0 to 1.5 and these months were characterized as sufficiently humid. For comparison, in 2019 the HTC ratio was not calculated only for three months: January, February, December (Table 2).

\section{Table 2}

Characteristics of hydrometeorological conditions in the south of Odessa Region for 2019

\begin{tabular}{lcccc}
\hline \multicolumn{1}{c}{ Months } & $\begin{array}{c}\text { Precipitation, } \\
\mathrm{mm}\end{array}$ & $\begin{array}{c}\text { Average } \\
\text { temperature, }{ }^{\circ} \mathrm{C}\end{array}$ & $\begin{array}{c}\text { Sum of active } \\
\text { temperatures }\left(\mathrm{t}_{\text {ac } \gg 10)}\right){ }^{\circ} \mathrm{C}\end{array}$ & HTC \\
\hline January & 32.2 & 2.2 & 0 & - \\
February & 42.4 & 9.7 & 0 & - \\
March & 31.2 & 11.4 & 353 & 0.9 \\
April & 40.1 & 12.7 & 381 & 1.1 \\
May & 29.9 & 19.6 & 608 & 0.5 \\
June & 42.1 & 22.7 & 681 & 0.6 \\
July & 39.2 & 25.5 & 791 & 0.5 \\
August & 28.9 & 24.9 & 772 & 0.4 \\
September & 31.5 & 21.1 & 633 & 0.5 \\
October & 29.1 & 14.2 & 440 & 0.7 \\
November & 41.2 & 10.5 & 315 & 1.3 \\
December & 49.8 & 3.4 & 0 & - \\
\hline
\end{tabular}

Severe and moderate droughts in 2019 were recorded for 7 months and only two months - April and November with a coefficient of HTC 1.1-1.3 were characterized as sufficiently wet. The HTC indicator affected the extensivity and intensity of cestodes in chickens. Among 1965 studied chickens, 329 (16.7\%) were infested with cestodes (Table 3).

In January, February and December, cestode eggs were not found in poultry manure. In March, the HTC coefficient was 0 but among 79 studied chickens, only $8(10.1 \%)$ had cestodiasis with an average intensity of $11.2 \pm 2.1$ eggs per $1 \mathrm{~g}$ of feces. At HTC $1.0-1.5$ (sufficient wet) the extent of chicken cestodiasis was in the range of $22.6-30.1 \%$ with an average intensity of $18.4 \pm 3.4$ eggs in $1 \mathrm{~g}$ of feces. In 2019, 2254 chickens were studied, 629 (28.2\%) were infested with cestodiasis (Table 4). 
Table 3

Dynamics of cestodes in chickens in 2017 on farms in the south of Odessa Region

\begin{tabular}{lccccc}
\hline \multicolumn{1}{c}{ Months } & HTC & $\begin{array}{c}\text { Studied } \\
\text { heads }\end{array}$ & $\begin{array}{c}\text { Infested } \\
\text { heads }\end{array}$ & EI, \% & $\begin{array}{c}\text { II, eggs } \\
\text { in 1 g of feces }\end{array}$ \\
\hline January & - & 117 & - & - & - \\
February & - & 198 & - & - & - \\
March & - & 79 & 8 & 10.1 & $11.2 \pm 2.1$ \\
April & 1.5 & 124 & 28 & 22.6 & $13.1 \pm 0.8$ \\
May & 1.0 & 170 & 42 & 24.7 & $19.9 \pm 1.1$ \\
June & 0.8 & 168 & 34 & 20.2 & $22.1 \pm 3.4$ \\
July & 0.5 & 181 & 31 & 17.1 & $17.6 \pm 0.9$ \\
August & 0.4 & 96 & 16 & 16.7 & $20.2 \pm 1.2$ \\
September & 0.8 & 245 & 91 & 37.1 & $29.6 \pm 0.5$ \\
October & 1.4 & 209 & 63 & 30.1 & $22.4 \pm 2.2$ \\
November & - & 275 & 16 & 5.8 & $7.2 \pm 0.8$ \\
December & - & 103 & - & - & - \\
$\quad$ Total: & - & 1965 & 329 & 16.7 & - \\
\hline
\end{tabular}

\section{Table 4}

Dynamics of cestodiasis in chickens in 2019 on farms in the south of Odessa Region

\begin{tabular}{lccccc}
\hline \multicolumn{1}{c}{ Months } & HTC & $\begin{array}{c}\text { Studied } \\
\text { heads }\end{array}$ & $\begin{array}{c}\text { Infested } \\
\text { heads }\end{array}$ & EI, \% & $\begin{array}{c}\text { II, eggs } \\
\text { in 1 g of feces }\end{array}$ \\
\hline January & - & 76 & - & - & - \\
February & - & 204 & 26 & 12.7 & $5.6 \pm 1.0$ \\
March & 0.9 & 105 & 29 & 27.6 & $12.9 \pm 2.1$ \\
April & 1.1 & 99 & 34 & 34.3 & $17.7 \pm 0.6$ \\
May & 0.5 & 244 & 102 & 41.8 & $28.2 \pm 2.4$ \\
June & 0.6 & 201 & 81 & 40.2 & $22.5 \pm 1.5$ \\
July & 0.5 & 175 & 56 & 32.0 & $24.4 \pm 0.9$ \\
August & 0.4 & 124 & 36 & 29.0 & $18.6 \pm 1.3$ \\
September & 0.5 & 207 & 91 & 43.9 & $21.2 \pm 2.7$ \\
October & 0.7 & 302 & 105 & 34.7 & $26.5 \pm 1.4$ \\
November & 1.3 & 311 & 64 & 20.5 & $18.1 \pm 0.5$ \\
December & - & 206 & 5 & 2.4 & $7.2 \pm 0.2$ \\
$\quad$ Total: & - & 2254 & 629 & 28.2 & - \\
\hline
\end{tabular}

In January 2019, among 76 studied chickens, cestodiasis was not registered in their eggs, while in 2017, such cestodiasis in eggs were not registered for three months: January, February, December. At HTC 1.1-1.3 among 410 studied chickens, 98 (23.9\%) were affected by cestodiasis. In the case of HTC from 0.4 to 0.9 among 1358 studied chickens, $500(36.8 \%)$ were affected by cestodiasis.

The nature of hydrometeorological conditions, moving in the direction of warming and severe and moderate droughts directly affects the increase of extensivity of raillietinosis in chickens. In 2017, 107 ants were studied by the compressor method, $21(19.6 \%)$ ants were infested with cysticercoids Raillietina echinobothrida with an intensity of 1 to 3 (Fig. 1). In 2019, among 116 studied ants, 30 (25.9\%) were infested with an intensity of 1 to 4 .

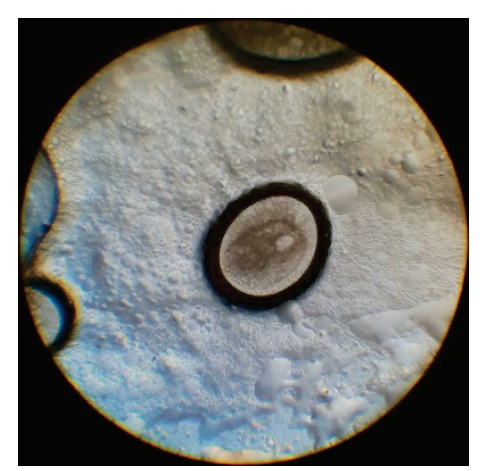

Fig. 1. Cysticercoid Raillietina echinobothrida in the abdominal cavity of the ant Tetramorium caespitum

In 2017, the excretion of cestodes with poultry feces was registered from March to November with an extensivity of $5.8 \%$ to $37.1 \%$, while in 2019 the hatching of cestode eggs was recorded from February with an extensivity of $12.7 \%$ to December with EI $2.4 \%$ (Fig. 2).

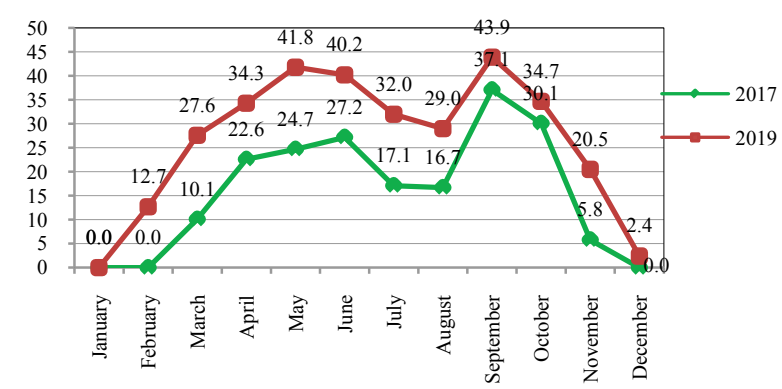

Fig. 2. Seasonal dynamics of chicken cestodes (2017 and 2019)

According to the monitoring, two peaks of the highest extensivity of cestodiasis were registered: the first - in May, the second - in September, but in 2019 they were 1.7 and 1.2 times higher. According to the species guide for domestic chickens in 2017, four species of cestodes were identified: Raillietina echinobothrida, R. tetragona, R. cesticillus and Davainea proglottina (Table 5).

Table 5

Species composition of cestodes of chickens in 2017 on farms in the south of Odessa Region

\begin{tabular}{|c|c|c|c|c|c|c|}
\hline HTC & Duration & $\begin{array}{l}\text { Total amount of } \\
\text { infested heads }\end{array}$ & $\begin{array}{c}\text { Raillietina } \\
\text { echinobothrida }\end{array}$ & $\begin{array}{l}\text { Raillietina } \\
\text { tetragona }\end{array}$ & $\begin{array}{l}\text { Raillietina } \\
\text { cesticillus }\end{array}$ & $\begin{array}{l}\text { Davainea } \\
\text { proglottina }\end{array}$ \\
\hline & & 172 & 109 & 21 & 24 & 18 \\
\hline $1.0-1.5$ & 3 months & 133 & 22 & 40 & 39 & 32 \\
\hline
\end{tabular}

According to the results of our research in mild and moderate droughts, which lasted 4 months, $R$. echinobothrida dominates (63.4\%). The infestation of chickens with $R$. tetragona was $12.2 \%, R$. sesticillus $-13.9 \%$ and D. proglottina $-10.5 \%$, which is $80.7 \%, 78.1 \%$ and $83.4 \%$ less compared to $R$. echinobothrida. In the wet period, which lasted 3 months, $R$. tetragona $(30.1 \%)$, $R$. sesticillus (29.3\%) and D. proglottina (24.1\%) dominated, due to the presence of a large number of beetles (intermediate hosts) and $R$. echinobothrida was recorded in chickens (16.5\%).

During the long dry period which lasted 7 months in 2019, R. echinobothrida (74.2\%) dominanted among the chicken cestodes, which is $14.6 \%$ more than in the same period in 2017 (Table 6).

Table 6

Species composition of cestodes of chickens in 2019 on farms in the south of Odessa Region

\begin{tabular}{ccccccc}
\hline HTC & Duration & $\begin{array}{c}\text { Total amount } \\
\text { of infested } \\
\text { heads }\end{array}$ & $\begin{array}{c}\text { Raillietina } \\
\text { echinobothrida }\end{array}$ & $\begin{array}{c}\text { Raillietina } \\
\text { tetragona }\end{array}$ & $\begin{array}{c}\text { Raillietina } \\
\text { cesticillus }\end{array}$ & $\begin{array}{c}\text { Davainea } \\
\text { proglottina }\end{array}$ \\
\hline $0.4-0.8$ & 7 months & 500 & 371 & 49 & 54 & 26 \\
$1.0-1.5$ & 2 months & 98 & 13 & 38 & 27 & 20 \\
\hline
\end{tabular}

So, invasion of chickens with $R$. tetragona decreased by $24.5 \%$, R. cesticillus - by $22.3 \%$ and $D$. proglottina - by $50.5 \%$. During the rainy season, which lasted 2 months, $R$. tetragona (38.8\%), $R$. cesticillus (27.5\%), D. proglottina $(20.4 \%)$ dominated among the cestodes and the invasiveness of $R$. echinobothrida was only $13.3 \%$. An analysis of the results shows that in the south of the Odessa Region of Ukraine, a gradual increase in the average daily temperature is recorded and a decrease in the amount of precipitation affects the coefficient of HTC, which, in turn, indicates a longer duration of strong and medium droughts. Climatic conditions in the south of Ukraine contribute to the spread of chicken cestodiasis and to the indicators of the extensivity and intensity of invasion.

\section{Discussion}

The territory of the southern districts of Odessa Oblast is located in the southwestern part of the Steppe agro climatic zone of Ukraine. According to the regional agrochemical laboratory, the structural composition of the southern black soils is characterized by insignificant dispersion of the upper soil layer, and the lower ones have a granular structure. The physical condition of soils and the physical processes that occur in them is one of the most important indicators that contribute to the growth of the interme- 
diate host population - ants and determine the preservation of the viability of helminth eggs. It has been established that the distribution and intensity of tapeworms is quite high in conditions of intensive chicken rearing and they are transmitted by various species of invertebrate hosts through bird droppings (Harikrishnan \& Ponnudurai, 2010).

Precipitation is one of the most unstable elements of the climate and, at the same time, its quantity and seasonal distribution in Southern Ukraine are of particular importance in relation to the spread of bird helminthiases. Differences in the spread of parasitic infection can be caused by differences in the climatic conditions of the region, the presence of intermediate hosts, or the way chickens are kept, as previously stated (Hange et al., 2007; Percy et al., 2012).

Magwisha et al. (2002) reported that climatic conditions (temperature and humidity) can change the population dynamics of parasites, which leads to changes in the spread and intensity of helminth infections in general.

Among the factors restraining the development of young birds and the productivity of adult birds are invasive diseases, in particular cestodiasis. Poultry cestodiases are quite common throughout the world, but mostly in the countries with a hot and temperate warm climate (Kurt et al., 2008; Hussen et al., 2012). Under the ecogeographic conditions of the South of Ukraine, the distribution, seasonal, and age-related dynamics of bird cestodiasis are influenced by complex phenomena due to the wide influence of abiotic and biotic environmental factors. Among them, climatic factors are of great importance and, first of all, temperature, changes in the nature of nutrition and lifestyle of the hosts, ecology and development cycles of intermediate hosts of Railletina and Davainea cestodes (entomophagous ants Tetramorium caespitum (Formiccidae), beetles - ground beetles Opatroides frater (Coleoptera), Amoebothenia (earthworms Eisenia foetida, Lumbricus rubellus (Lumbricidae), Muscidae (housefly Musca domestica L.), which affect the possibility and probability of infection of the birds with cestodes (Bogach et al., 2013).

Differences in the spread of parasitic diseases can be caused by specific various climatic conditions of the region, the presence of intermediate hosts, or the way in which birds are kept (Magwisha et al., 2002; Hange et al., 2007; Percy et al., 2012). This is also confirmed by our data - in the southern districts of Odessa Region in Ukraine, the distribution of chicken cestodiasis depends on the hydrothermal coefficient and, accordingly, the growth of population of Formica ants.

Significant correlation between seasonality and the spread of gastrointestinal parasites was observed in the Gannavaram area, Andhra Pradesh and its environs. The data indicated their high prevalence during the rainy season $(43.4 \%)$, followed by the summer $(38.9 \%)$ and winter $(17.7 \%)$ periods (Sreedevi et al., 2016). The ambient temperature and high rainfall in the Jammu region contribute to the more rapid development and spread of various stages of bird nematodes and cestodes (Katoch et al., 2012). In domestic chickens from Tanzania during the wet and dry periods, the presence of $R$. echinobothrida (41.3\% and 46.3\%, respectively), $R$. tetragona $(25.3 \%$ and $21.3 \%$, respectively), $R$. cesticillus $(8.7 \%$ and $2.7 \%$, respectively) were registered (Permin et al., 1997).

In the period from March 2005 and August 2006, a study was conducted to identify and evaluate the spread of parasites of local chickens in the semi-arid region of Kenya. Thus, $R$. echinobothrida (33.3\%) and D. proglottina $(19.4 \%)$ were the two most important types of cestodes (Mungube et al., 2008). So, our results supplement the data on the distribution of birds' cestodiasis, which is confirmed by the results of other researchers from other countries around the world.

There are scant but interesting data concerning poultry infection with helminths in the region of Aswan province, Upper Egypt. From April 2016 to March 2017, 276 birds were examined (156 chickens and 120 domestic pigeons). The study showed that the overall prevalence of parasitic diseases was 55.8\% (154/276). In addition, 59.1\% of the chickens had mixed infections with four cestode and three nematode species. Among the cestodes, the most common species were $R$. tetragona (16.0\%), followed by $R$. echinobothrida (11.0\%), Cotugnia digonopora $(6.4 \%)$ and $R$. cesticillus $(1.3 \%)$. Meanwhile the highest rates of infection were found in summer and the lowest were recorded in winter (El-Dakhly et al., 2019).

A significant difference was found between the distribution of helminths in different agroecological zones of Ethiopia. The highest preva- lence was observed in lowland areas. This suggests that agro ecology has a great influence on the spread of parasites. The main types of cestodes were $R$. echinobothrida $(25.8 \%)$, R. tetragona $(45.7 \%), R$. cesticillus (5.6\%), Amoebotaenia sphenoides $(40.5 \%)$ and D. proglottina $(1.1 \%)$ (Eshetu et al., 2001).

The high prevalence of cestodiasis in domestic chickens can be explained by the fact that chickens were kept on a livestock pasture and had access to invasion of the environment and intermediate hosts such as ants, beetles, earthworms, etc. Thus, the study of the seasonal dynamics of chicken raillietinosis is of great importance for determining the sources of invasion, as well as to carry out the deworming on time. To know the peak of invasion allows one to develop a scheme for deworming of poultry, which will be relevant for this region and differ from the generally accepted time.

\section{Conclusion}

According to the hydrothermal coefficient in the south of Odessa Region of Ukraine, moderate and severe periods of drought have increased from 4 to 7 months, which affects the increase in the population of intermediate hosts of chicken cestodiasis - ants belonging to the genus Formi$c a$. In 2017, the isolation of cestode eggs from bird droppings was recorded from March to November with an intensity of $5.8 \%$ to $37.1 \%$ with the highest rates in June (27.2\%) and September (37.1\%), whereas in 2019, cestode eggs were recorded from February to December (from 12.7\% to $2.4 \%$ ), with high rates in May (41.8\%) and September (43.9\%). The species composition of chicken cestodes is represented by four species: $R$. echinobothrida (74.2\%), which dominates due to the longer low HTC, as well as $R$. tetragona $(9.8 \%), R$. cesticillus $(10.8 \%)$ and D. proglottina $(5.2 \%)$.

\section{References}

Abdelqader, A., Gauly, M., Wollny, C. B., \& Abo-Shehada, M. N. (2008). Prevalence and burden of gastrointestinal helminthes among local chickens, in Northern Jordan. Preventive Veterinary Medicine, 85(1-2), 17-22.

Blum, A. J., \& Hotez, P. J. (2018). Global "worming": Climate change and its projected general impact on human helminth infections. PLoS Neglected Tropical Diseases, 12(7), e0006370.

Bogach, M. V., \& Stoyanova, V. Y. (2020). Antihelmintic effectiveness of preparations in experimental chicken rayetinosis. Veterinary Science, Technologies of Animal Husbandry and Nature Management, 5, 22-25.

Bogach, M. V., Sklaruk, V. G., Manko, O. G., \& Danileiko, Y. M. (2013). Ekolohiya parazytarnykh khvorob domashn'oyi ptytsi [Ecology of parasitic diseases of poultry]. Tutorial, Odessa (in Ukrainian).

Bogach, M. V., Stoianova, V. Y., \& Pivovarova, I. V. (2019). Poshyrennya tsestodoziv kurey v ptakhohospodarstvakh Pivdnya Ukrayiny [Distribution of cestodes of chickens on poultry farms in the South of Ukraine]. Agrarian Bulletin of the Black Sea Region: A collection of scientific works. Veterinary Sciences, 93, 140-143 (in Ukrainian).

Boyko, A., Brygadyrenko, V., Shendryk, L., \& Loza, I. (2009). Estimation of the role of antropo-zoonosis invasion agents in the counteraction to bioterrorism. Counteraction to Chemical and Biological Terrorism in East European Countries. NATO Science for Peace and Security Series A: Chemistry and Biology. Springer Nature, 309-315.

Boyko, O. O., Zazharska, N. M., \& Brygadyrenko, V. V. (2016). The influence of the extent of infestation by helminths upon changes in body weight of sheep in Ukraine. Visnyk of Dnipropetrovsk University, Biology, Ecology, 24(1), 3-7.

Cadmus, K. J., Mete, A., Harris, M., Anderson, D., Davison, S., Sato, Y., Helm, J., Boger, L., Odani, J., Ficken, M. D., \& Pabilonia, K. L. (2019). Causes of mortality in backyard poultry in eight states in the United States. Journal of Veterinary Diagnostic Investigation, 31(3), 318-326.

Daxno, I. S., \& Daxno, Y. I. (2010). Ekolohichna hel'mintolohiya [Ecological Helminthology]. Sumy (in Ukrainian).

El-Dakhly, K. M., El-Seify, M. A., Mohammed, E. S., Elshahawy, I. S., Fawy, S. A., \& Omar, M. A. (2019). Prevalence and distribution pattern of intestinal helminths in chicken and pigeons in Aswan, Upper Egypt. Tropical Animal Health and Production, 51(3), 713-718.

Eshetu, Y., Mulualem, E., Ibrahim, H., Berhanu, A., \& Aberra, K. (2001). Study of gastro-intestinal helminths of scavenging chickens in four rural districts of Amhara region, Ethiopia. Revue Scientifique et Technique, 20(3), 791-796.

Fox, N. J., Marion, G., Davidson, R. S., White, P. C., \& Hutchings, M. R. (2012) Livestock helminths in a changing climate: Approaches and restrictions to meaningful predictions. Animals, 2(1), 93-107. 
Gornall, J., Betts, R., Burke, E., Clark, R., Camp, J., Willett, K., \& Wiltshire, A. (2010). Implications of climate change for agricultural productivity in the early twenty-first century. Philosophical Transactions of the Royal Society B, 365, 2973-2989.

Hange, R. R., Raote, Y. V., \& Jayraw, A. K. (2007). Prevalence of helminth parasites in desi fowl (Gallus gallus domesticus) at Parbhani. Journal of Parasitic Diseases, 31(1), 61-64.

Harikrishnan, T. J., \& Ponnudurai, G. (2010). Occurrence of Cotugnia diagonopora in young broilers. Indian Veterinary Journal., 87(8), 831-832.

Hassouni, T., \& Belghyti, D. (2006). Distribution of gastrointestinal helminths in chicken farms in the Gharb region-Morocco. Parasitology Research, 99(2), 181-183.

Hu, Y., Cheng, H., \& Tao, S. (2017). Environmental and human health challenges of industrial livestock and poultry farming in China and their mitigation. Environment International, 107, 111-130.

Hübner, M. P., Layland, L. E., \& Hoerauf, A. (2013). Helminths and their implication in sepsis - a new branch of their immunomodulatory behaviour? Pathogens and Disease, 69(2), 127-141.

Hussen, H., Chaka, H., Deneke, Y., \& Bitew, M. (2012) Gastrointestinal helminths are highly prevalent in scavenging chickens of selected districts of Eastern Shewa zone, Ethiopia. Pakistan Journal of Biological Sciences, 15(6), 284-289.

Karshima, S. N., Maikai, B. V., \& Kwaga, J. K. P. (2018). Helminths of veterinary and zoonotic importance in Nigerian ruminants: A 46-year meta-analysis (19702016) of their prevalence and distribution. Infectious Diseases of Poverty, 7, 52.

Katoch, R., Yadav, A., Godara, R., Khajuria, J. K., Borkataki, S., \& Sodhi, S. S. (2012). Prevalence and impact of gastrointestinal helminths on body weight gain in backyard chickens in subtropical and humid zone of Jammu, India. Joumal of Parasitic Diseases, 36(1), 49-52.

Kurt, M., \& Acici, M. (2008). Cross-sectional survey on helminth infections of chickens in the Samsun region, Turkey. Dtsch Tierarztl Wochenschr, 115(6), 239-242.

Lorencena, M. C., Southier, L. F. P., Casanova, D., Ribeiro, R., \& Teixeira, M. (2018). A framework for modelling, control and supervision of poultry farming. International Journal of Production Research, 58(10), 3164-3179.

Magwisha, H., Kassuku, A., Kyvsgaard, N., \& Permin, A. A. (2002). Comparison of the prevalence and burdens of helminth infections in growers and adult free range chickens. Tropical Animal Health and Production, 34(3), 205-214.

McSorley, H. J., \& Maizels, R. M. (2012). Helminth infections and host immune regulation. Clinical Microbiology Reviews, 25(4), 585-608.

Mendelsohn, N. (2008). The impact of climate change on agriculture in developing countries. Journal of Natural Resources Policy Research, 1(1), 5-19.

Mungube, E. O., Bauni, S. M., Tenhagen, B. A., Wamae, L. W., Nzioka, S. M., Muhammed, L., \& Nginyi, J. M. (2008). Prevalence of parasites of the local scavenging chickens in a selected semi-arid zone of Eastern Kenya. Tropical Animal Health and Production, 40(2), 101-109.
Paliy, A. P., Mashkey, A. M., Sumakova, N. V., \& Paliy, A. P. (2018). Distribution of poultry ectoparasites in industrial farms, farms, and private plots with differrent rearing technologies. Biosystems Diversity, 26(2), 153-159.

Paliy, A. P., Sumakova, N. V., Mashkey, A. M., Petrov, R. V., Paliy, A. P., \& Ishchenko, K. V. (2018). Contamination of animal-keeping premises with eggs of parasitic worms. Biosystems Diversity, 26(4), 327-333.

Paliy, A., Sumakova, N., Petrov, R., Shkromada, O., Ulko, L., \& Palii, A. (2019). Contamination of urbanized territories with eggs of helmiths of animals. Biosystems Diversity, 27(2), 118-124.

Percy, J., Pias, M., Enetia, B. D., \& Lucia, T. (2012). Seasonality of parasitism in free range chickens from a selected ward of a rural district in Zimbabwe. African Journal of Agricultural Research, 7(25), 3626-3631.

Permin, A., Magwisha, H., Kassuku, A. A., Nansen, P., Bisgaard, M., Frandsen, F., \& Gibbons, L. (1997). A cross-sectional study of helminths in rural scavenging poultry in Tanzania in relation to season and climate. Journal of Helminthology, 71(3), 233-240.

Puttalakshmamma, G. C., Ananda, K. J., Prathiush, P. R., Mamatha, G. S., \& Rao, S. (2008). Prevalence of gastrointestinal parasites of poultry in and around Bangalore. Veterinary World, 1(7), 201-202.

Radfar, M. H., Khedri, J., Adinehbeigi, K., Nabavi, R., \& Rahmani, K. (2012). Prevalence of parasites and associated risk factors in domestic pigeons (Columba livia domestica) and free-range backyard chickens of Sistan region, east of Iran. Journal of Parasitic Diseases, 36(2), 220-225.

Saif, Y. M., Fadly, A. M., Glisson, J. R., McDonald, L. R., Nolan, L. K., \& Swayne, E. F. (2008). Diseases of poultry. Blackwell Publication, London.

Sonntag, W. I., Spiller, A., \& von Meyer-Höfer, M. (2019). Discussing modern poultry farming systems - insights into citizen's lay theories. Poultry Science, 98(1), 209-216.

Sreedevi, C., Jyothisree, C., Rama Devi, V., Annapurna, P., \& Jeyabal, L. (2016). Seasonal prevalence of gastrointestinal parasites in desi fowl (Gallus gallus domesticus) in and around Gannavaram, Andhra Pradesh. Journal of Parasitic Diseases, 40(3), 656-661.

Stepanenko, S. N. (2007). Zmina klimatu. Shcho nas chekaye u maybutn'omu [Climate change. What awaits us in the future]. Bulletin of the Hydrometeorological Center of the Black and Azov Seas, 2,8 (in Ukrainian).

Velusamy, R., Basith, S. A., Harikrishnan, T. J., Ponnudurai, G., Anna, T., \& Ramakrishnan, S. (2014). Ground beetle, Opatroides frater (Coleoptera) as natural intermediate host for the poultry tapeworm, Raillietina cesticillus. Journal of Parasitic Diseases, 38(1), 128-131.

Wells, K., Gibson, D. I., Clark, N. J., Ribas, A., Morand, S., \& McCallum, H. I. (2018). Global spread of helminth parasites at the human-domestic animalwildlife interface. Global Change Biology, 24(7), 3254-3265.

Winter, J., Rehbein, S., \& Joachim, A. (2018). Transmission of helminths between species of ruminants in Austria appears more likely to occur than generally assumed. Frontiers Veterinary Science, 5, 30. 